\title{
Comparative study for assessing the OSH relationship to the quality of construction projectsinEgypt
}

\author{
Sherif Mohamed Ahmed ali \\ Assistant Professor, Department of civil construction and architecture \\ Vice Dean for Student Affairs \\ Faculty of Technology and Education, Suez University, Suez, Egypt \\ shrifmohammed470@gmail.com \\ Mohamed Amin Saad \\ Assistant Professor, Department of civil construction and architecture \\ Faculty of Technology and Education, Suez University, Suez, Egypt \\ Bassam Abdelsalam Abdelsalam \\ Professor, Department of civil construction and architecture \\ Faculty of Technology and Education, Suez University, Suez, Egypt
}

i@11@ms@iaasl@s@malsalsdbasaassab

Ewais Farag Ali,

Civil and Architectural Constructions Department, Faculty of Technology and Education, Suez University, Suez, Egypt

ewaisfarag253@gmail.com

\section{ABSTRACT}

Background: Construction and architectural projects (CAPs) play a significant role in the economic development of most countries. The construction industry in Egypt has significantly grown in recent years. Due to this growth, the number of occupational accidents in the country's construction industry has also increased.

Methods: This study aimed to assess the Occupational Safety and Health (OSH) field. Then, the assessment effects on the construction project quality are evaluated. The statistical analysis of the questionnaire surveys conducted on project safety, quality, and executive management at construction companies based on the Statistical Package for the Social Sciences (SPSS).

Results: After comparing two sites, the research results indicated differences in completion times and overall costs between the two sites. $70 \%$ of the respondents agreed that the completion times, costs, and project qualities vary between the two sites. About $92 \%$ of the sample completely agreed and were willing to follow the international laws, which stipulate the principles of OSH in construction sites. They also agreed that there should be an increased understanding of the importance of OSH management in sites, which can help prevent clashes between the two departments.

Conclusions: Companies should hire a social worker to take care of the workers, help them solve their problems, and ensure that safety standards are being met in the construction sites. In addition, regular medical examinations of all workers must be conducted to ensure that they are free from any occupational, non-infectious, or infectious diseases, such as the coronavirus.

\section{Keywords:}

Construction management; Construction Safety; Occupational safety and health (OSH), Occupational risk assessment; risk assessment; total quality management (TQM). 


\section{Introduction}

The increasing of accidents and deaths in building construction projects is classified as hazardous industries in the world [1]. The accidents ratio of construction sector in the U.S. is more than 50\% comparable with other industries [2]. Construction contractors have traditionally been held responsible for Occupational Safety and Health (OSH) on construction sites [3]. In 1992, the EU Construction Sites Directive (92/57/EEC) [4] put heavy responsibility for OSH on the client. Many occupational accidents are maybe due to several reasons such as organization, planning and co-ordination [5]. There is a lack of studies about the OSH costs in construction industry. OSH costs and accidents during a construction project were compared by [6] in Turkey. Korkutan [7] studied the overall costs of 25 building construction projects with OSH costs. The International Labor Organization (ILO) stated that the numbers of deaths and accidents were 2.3 and 313 million workers respectively in (2015). The global cost in OSH was about 2.8 trillion US dollars with ratio of $4 \%$ of the world's gross domestic product per year [8]. The OSH management in the construction fields must be concerned. However, a lot of research had been interested of the workers physical health. Chartered Institute of Building [9] reported that most construction workers are exposed to stresses and depression due to a continuously work like complicated work, inadequate conditions, time pressed and other factors [10]. Stress is closely related to physical health [11]. The occupational risk assessment in construction sites was performed using various methods to reduce and prevent subjectivity in estimating occupational accident severity [12-15]. Most researchers interested of the occupational hazards and the hypothesis testing of explanatory dependent variables. However, occupational injury risks have not been significantly reduced. This long-standing problem can be seen in the traditional practices which approach construction safety [16]. The safety culture and training can be reduced the occupational risks [17]. The utilizing of numerous emerging technologies such as sensing technologies and cyber-physical systems are contributed to reduces the dangerous statues. Alerts are playing a significant role to care and avoid the danger zones [18-21]. OSH has been improved on a worldwide range at construction society based on publications, relevant standards, and implementation of stringent regulations and laws [22, 23]. Nevertheless, the accidents in the construction sectors are occurred increasingly compared with other industries [24]. Razuri, et al [25] suggested that developed a safety performance using a combination of practices. Hence, meaning that there is no single formula to prevent accidents. The scaffolding, staging, portable ladders and floor openings are the main problems to fall injuries from heights [26-28]. Due to the lack of fall protection of OSH administration, most procedures cited in construction standards in 2014 [29]. Achieve zero accidents and ultimate safety performance is the recent topic of industry [30]. 
Despite the amount of substantial research and improvements that have been made through the years, accident rates in construction are still high [31]. Practical tools directed towards enhancing safety performance in the construction industry are still lacking [32]. The construction industry in Europe (EU-28) had the highest share of fatal occupational accidents in 2015, with more than one in five accidents [33]. The construction industry in Egypt provides employment opportunities for over 120 thousand workers in the public sector and their likes of that number in the private sector; one of the most important causes of accidents in the construction sites according to studies: the weakness of application of OSH in construction companies [34].

\section{Research methodology}

This study examines the evaluation of construction and architectural projects of the $\mathrm{OSH}$ impact on the quality and management of the projects in Egypt. This research is hypothetical to prove that OSH has a direct relationship with the quality of projects based on the theoretical and practical approach. The objective of the theoretical approach is to be used in the practical approach, so that research have the approach of theoreticalpractical comparison.

\subsection{Researchtools:}

A quantitative questionnaire was used to verify the hypotheses and over 100 forms were excluded because the answer is doubtful, and the OSH and quality were involved in the questionnaire. The reconnaissance works demo on the number of questionnaires, and

it was missing the questionnaire a set of questions to be evaluated and added as was missing the extra part of the study, demographic and modify the survey. Based on this, the final form was reached, and the results of the survey were analyzed by statistical methods and the conclusion of the reality of construction companies in Egypt through their projects. The survey sample was conducted on a site, quality, OSH and executive managers at construction companies that have construction projects in Egypt. SPSS statistical analysis was used to determine the results of the questionnaire as follows:

\section{a) Studymethod}

Based on the nature of the research and information, the descriptive method was used where this method depends on the phenomenon study as it actually exists in reality. It is interested in an accurate description and is expressed in a qualitative and quantitative expression. The qualitative expression is explaining the characteristics of the phenomenon. The quantitative parameter is providing a descriptive number which attributes the phenomenon or size and association degrees with different phenomena. 


\section{b) Study sample}

A random sample directed representative of the community study includes the 120 engineers and managers working in construction and architectural sites in Egypt. The engineers and managers were selected according to statistical equations specified for the appropriate minimum sample size representing the community study.

Cronbach's Alpha coefficient was used to measure the stability and truthfulness of the study tools as shown in Table 1. The self-truthfulness is measured by calculate the square root of the stability coefficient. The truthfulness of the current study sample is reached up to 0.883 , which indicates that the questionnaire has a high degree of the honesty.

\section{c) Statistical method}

Five responses were included in the questionnaires and were assigned numerical values: 5 for "strongly agree" 4 for "agree" 3 for "often" 2 for "sometimes" and 1 for "disagree" The results based on the 5-items Likert scale are shown in Table 2.

\section{d) Results and discussions}

The demographic analysis of the questionnaires prepared in this study involved various parameters, including job type, age, years of experience, educational level, social status, and gender. Table 3 presents the demographic analysis of the study sample. The questionnaire surveys were conducted on all the project sites and involved safety and quality engineers in different locations. Therefore, the results represent a cross-section of construction sites throughout Egypt. The percentages according to job type were 13.3\%, $8.3 \%, 15.8 \%, 26.7 \%$, and $35.8 \%$ for safety director, quality director, implementation engineer, quality engineer, and safety engineer, respectively. About $48.3 \%$ were over 40 years old and $51.7 \%$ were between 22 to 40 years old. In terms of years of experience, $48.3 \%$, of the respondents had over 10 years of experience, 35\% have 5 to 10 years, and $16.7 \%$ have less than 5 years. In terms of educational level, 9.2\% had a Ph.D. degree, 11.7\% had an M.Sc. degree, and $79.2 \%$ had a B.Sc. degree. As for the social status, $82.5 \%$ were married and 17.5\% were single. Moreover, in terms of gender, $95.8 \%$ were male and $4.2 \%$ were female. The statistical analysis was conducted by calculating the main and standard deviations for each question in order to analyze each question's accuracy, as shown in Table 4. After analyzing the results of the 64 questions that the questionnaire worked on. Figs. 1 and 2 show the questionnaire results and illustrate the effect of the application of OSH on the quality of construction and architectural projects in Egypt. Fig. 3 presents the statistical analysis results for each question given by 120 respondents. 
The companies must promote a "safety first" organizational culture in all projects and working locations, create a database for the different types of accidents and their causes in order to avoid similar events in the future, and provide sufficient information and data about risk types surrounding each worker and the appropriate protection methods. Before beginning their work, all workers must also sign a safety document to signal their awareness and willingness to comply with the OSH requirements and instructions. The reasons for project loss include low quality and increased accidents. About $92 \%$ of the sample agreed to the idea that there should be an independent OSH management team in each construction company. In addition, over $80 \%$ strongly agreed to the idea that the OSH management must develop high efficiency in terms of injury treatment without any delayed medical support. Consequently, the application of OSH standards in a company would improve project quality.

Meanwhile, the OSH department must organize awareness lectures for the employees. About $80 \%$ of the sample completely agreed that studies must be conducted to come up with the best and safest methods to perform various tasks, thus reducing the psychological effects caused by accidents and industrial diseases. At the same time, this will strengthen relations between workers and the management, who will be perceived as caring for the safety and well-being of the workers by giving them importance in the workplace.

The OSH department must clarify with each worker the nature of the risks surrounding him/her depending on the construction site where he/she works. About $92 \%$ of the sample completely agreed and were willing to follow the international laws, which stipulate the principles of OSH in construction sites. They also agreed that there should be an increased understanding of the importance of OSH management in sites, which can help prevent clashes between the two departments. This is especially needed when, for example, the implementation department insists on executing a job without the application of OSH to the detriment of the company's reputation, while also increasing the risk of accidents and reducing project quality.

About 86 respondents agreed that the application of $\mathrm{OSH}$ standards in construction sites saves money and promotes the company's reputation. Meanwhile, according to 105 persons who completely agreed, adherence to OSH standards reduce litigation cases. For $96 \%$ of the sample who completely agreed, such standards increase the chances of meeting project schedules and deadlines. These also change the prevailing organizational culture regarding accidents and risks according to 91 persons. When comparing two different sites (same specifications and start times, but only one applied OSH standards), $70 \%$ of the respondents agreed that the completion times, costs, and project qualities vary 
between the two sites.

Companies must have an independent quality department according to 105 persons, as this reduces the pressures associated with the projects. Meanwhile, about $8 \%$ of the study sample completely agreed that having a deterrent law that obliges contractors to apply safety standards may have positive effects on the application of OSH standards in Egyptian companies. In fact, around $97 \%$ of the sample completely agreed that one of the reasons for poor project quality is that there is no independent quality department in the companies. In addition, preventive measures should be increased for the workers coming back from holidays and going to holidays, because chances of accidents in construction sites increase during those times. Therefore, companies must also review the wages and salaries to improve the workers' satisfaction and, in turn, increase the quality of their work. It is necessary to maintain an Internet connection in the OSH department so that it can benefit from the experiences of others by communicating with global specialists and keeping up to date with the latest methods and safety systems. The OSH department must also cooperate with the Ministry of Manpower, review and/or approve proposals regarding construction sites, and accommodate the need to hire someone who can oversee OSH standards compliance, thus reducing possible penalties.

Aside from the above, companies should hire a social worker to take care of the workers, help them solve their problems, and ensure that safety standards are being met in the construction sites. In addition, regular medical examinations of all workers must be conducted to ensure that they are free from any occupational, non-infectious, or infectious diseases, such as the coronavirus. Companies should also allow staff from international and local scientific magazines to visit construction sites, identify weaknesses, and allow researchers and universities to conduct scientific research regarding the project sites. In this way, companies can use their findings to improve their operations and increase the quality of projects.

It is necessary for the company management and OSH department to follow up OSH compliance in sites, keep pursuing developments, and continue using modern methods. Furthermore, they must have sufficient information to achieve quality standard requirements and increase the efficiency of information exchange between the various departments, thus improving the quality of the CAPs. Quality-related problem-solving processes must be done quickly as it can reduce the proportion of losses in the construction projects. All workers must be included in the process of development, and their suggestions must be duly considered to increase project quality. Moreover, tools to measure the performance of processes in CAPs must be developed. Companies should employ the principle of quality and consider it as the responsibility of each worker in addition to having a special system meant to raise project quality, such as examination of materials and endorsement of inspection reports, as mentioned by more than $80 \%$ of the respondents. 
The company management must recognize the importance of TQM in terms of the speed of construction, quality of performance, and economic cost of developing a proposed system as quickly and as effectively as possible. There should be a technical college devoted to applied sciences and $\mathrm{OSH}$ as well as secure work environments and TQM to qualify the skilled inspectors in the market. It is also necessary to develop a special OSH department in the universities and increase the amount of teaching materials

and credit hours for college students to further promote awareness of OSH and TQM. There should be a university condition to study $\mathrm{OSH}$ and train everyone according to his/her specialization so that no student receives a graduation certificate without having appropriate training on safety. The classification of construction companies under the Egyptian Federation for Construction and Building Contractors must consider the companies' experiences in striving for safe and secure work environments, preventing accidents and injuries, and maintaining TQM.

Finally, companies must review the complaints of office for workers and contractors, apply safety systems at work, and even do unannounced visits to different construction sites so that the workers know of their existence. 
Table 1: Reliability statistics

\begin{tabular}{cc}
\hline Cronbach's Alpha & No. of items \\
\hline 0.883 & 64
\end{tabular}

Table 2: Weight of the answers

\begin{tabular}{lcc}
\hline \multicolumn{1}{c}{ Response } & Weight & The weighted average \\
\hline Disagree & 1 & From 1 to 1.80 \\
Sometimes & 2 & From 1.81 to 2.60 \\
often & 3 & From 2.61 to 3.40 \\
Agree & 4 & From 3.41 to 4.20 \\
Strongly agree & 5 & Bigger than 4.20 \\
\hline
\end{tabular}

Table 3: Members distribution of the study sample according to the different variables

\begin{tabular}{|c|c|c|}
\hline \multirow[b]{2}{*}{ Job type } & Frequency & Percent \\
\hline & & \\
\hline 1- Director of the Department of safety & 16 & 13.3 \\
\hline 2- Director of quality management & 10 & 8.3 \\
\hline 3- Engineer implementation & 19 & 15.8 \\
\hline 4- Quality engineer & 32 & 26.7 \\
\hline 5- Safety engineer & 43 & 35.8 \\
\hline Total & 120 & 100.0 \\
\hline \multicolumn{3}{|l|}{ Person age } \\
\hline 1- larger from 40 & 58 & 48.3 \\
\hline 2 - from 22 to 40 & 62 & 51.7 \\
\hline Total & 120 & 100.0 \\
\hline \multicolumn{3}{|l|}{ No. of experience years } \\
\hline 1- Higher than 10 & 58 & 48.3 \\
\hline 2- From 5 to 10 & 42 & 35.0 \\
\hline 3- Less than 5 & 20 & 16.7 \\
\hline Total & 120 & 100.0 \\
\hline \multicolumn{3}{|l|}{ Education level } \\
\hline 1- Ph.D. & 11 & 9.2 \\
\hline 2- M.Sc. & 14 & 11.7 \\
\hline 3- B.Sc. & 95 & 79.2 \\
\hline Total & 120 & 100.0 \\
\hline \multicolumn{3}{|l|}{ Social status } \\
\hline 1- Married & 99 & 82.5 \\
\hline 2- Single & 21 & 17.5 \\
\hline Total & 120 & 100.0 \\
\hline \multicolumn{3}{|l|}{ Gender } \\
\hline 1- Male & 115 & 95.8 \\
\hline 2- Female & 5 & 4.2 \\
\hline Total & 120 & 100.0 \\
\hline
\end{tabular}


Table 4: Statistical analysis of questionnaire results

\begin{tabular}{|c|c|c|c|c|c|c|c|c|}
\hline & \multicolumn{5}{|c|}{ Valid Percent } & \multirow{2}{*}{ Mean } & \multirow{2}{*}{$\begin{array}{r}\text { Standard } \\
\text { div. }\end{array}$} & \multirow{2}{*}{ Result } \\
\hline & (1) & (2) & (3) & (4) & (5) & & & \\
\hline Q1 & 0 & 0 & 15.8 & 0 & 84.2 & 4.68 & 0.73 & (5) \\
\hline $\mathrm{Q} 2$ & 0 & 0 & 4.2 & 12.5 & 83.3 & 4.79 & 0.50 & (5) \\
\hline Q3 & 0 & 39.2 & 5.0 & 7.5 & 48.3 & 3.65 & 1.41 & (4) \\
\hline Q4 & 0 & 31.7 & 42.5 & 18.7 & 9.2 & 3.03 & 0.93 & (3) \\
\hline Q5 & 0 & 0 & 23.3 & 13.3 & 63.3 & 4.40 & 0.84 & (5) \\
\hline Q6 & 0 & 0 & 30.8 & 21.7 & 47.5 & 4.17 & 0.87 & (4) \\
\hline Q7 & 0 & 7.5 & 5 & 20.8 & 66.7 & 4.47 & 0.90 & (5) \\
\hline Q8 & 0 & 20 & 4.2 & 13.2 & 82.5 & 4.18 & 1.20 & (4) \\
\hline Q9 & 0 & 0 & 4.2 & 9.2 & 86.7 & 4.83 & 0.48 & (5) \\
\hline Q10 & 0 & 13.3 & 11.7 & 21.7 & 53.3 & 4.15 & 1.08 & (4) \\
\hline Q11 & 0 & 25 & 8.3 & 32.5 & 34.2 & 3.76 & 1.17 & (4) \\
\hline Q12 & 0 & 21.7 & 25.0 & 53.3 & 0 & 3.32 & 0.81 & (3) \\
\hline Q13 & 0 & 9.2 & 7.5 & 38.3 & 45.0 & 4.19 & 0.93 & (4) \\
\hline Q14 & 0 & 41.7 & 30.8 & 28.7 & 0.8 & 2.87 & 0.84 & (3) \\
\hline Q15 & 0 & 7.5 & 52.5 & 27.5 & 12.5 & 3.45 & 0.81 & (4) \\
\hline Q16 & 0 & 19.2 & 18.3 & 20.8 & 41.7 & 3.85 & 1.16 & (4) \\
\hline Q17 & 0 & 43.3 & 22.5 & 25.0 & 9.2 & 3.00 & 1.03 & (3) \\
\hline Q18 & 0 & 0.8 & 15.8 & 45.8 & 37.5 & 4.20 & 0.73 & (4) \\
\hline Q19 & 0 & 0 & 0 & 8.3 & 91.7 & 4.92 & 0.28 & (5) \\
\hline Q20 & 0 & 0 & 0 & 19.2 & 80.2 & 4.81 & 0.40 & (4) \\
\hline Q21 & 0 & 11.7 & 20.8 & 0.8 & 88.7 & 4.23 & 1.14 & (5) \\
\hline Q22 & 0 & 7.5 & 33.3 & 13.3 & 45.8 & 3.98 & 1.05 & (4) \\
\hline Q23 & 0 & 0.8 & 32.5 & 16.7 & 50.0 & 4.16 & 0.92 & (4) \\
\hline Q24 & 0 & 0 & 4.2 & 19.2 & 78.7 & 4.73 & 0.53 & (5) \\
\hline Q25 & 0 & 11.7 & 25.0 & 14.2 & 49.2 & 4.70 & 0.68 & (5) \\
\hline Q26 & 0 & 20.8 & 29.2 & 4.8 & 9.2 & 4.69 & 0.87 & (5) \\
\hline Q27 & 0 & 16.7 & 35.8 & 12.5 & 35.0 & 4.64 & 0.97 & (5) \\
\hline Q28 & 0 & 8.3 & 14.2 & 14.2 & 83.3 & 4.92 & 0.40 & (5) \\
\hline Q29 & 0 & 12.5 & 0.8 & 15.0 & 71.7 & 4.35 & 0.97 & (5) \\
\hline Q30 & 0 & 0 & 0.8 & 11.7 & 87.5 & 4.22 & 1.34 & (5) \\
\hline Q31 & 0 & 0.8 & 11.7 & 7.5 & 80.0 & 3.81 & 1.27 & (4) \\
\hline Q32 & 0 & 0.8 & 0 & 41.7 & 57.5 & 4.26 & 1.10 & (5) \\
\hline Q33 & 0 & 12.5 & 7.5 & 4.2 & 75.8 & 4.29 & 1.15 & (5) \\
\hline Q34 & 0 & 9.2 & 35.0 & 15.8 & 40.0 & 4.27 & 0.95 & (5) \\
\hline Q35 & 0 & 0 & 48.7 & 4.2 & 49.2 & 3.96 & 1.16 & (4) \\
\hline Q36 & 0 & 4.2 & 0 & 17.5 & 78.3 & 4.52 & 0.63 & (5) \\
\hline Q37 & 0 & 7.5 & 4.2 & 0 & 88.3 & 4.01 & 1.10 & (4) \\
\hline Q38 & 0 & 11.7 & 0 & 0.8 & 87.5 & 3.38 & 0.92 & (3) \\
\hline Q39 & 0 & 0 & 4.2 & 0 & 95.8 & 3.66 & 1.13 & (4) \\
\hline Q40 & 0 & 11.7 & 0 & 30.0 & 58.3 & 4.33 & 1.01 & (4) \\
\hline Q41 & 7.5 & 11.7 & 0 & 13.3 & 67.5 & 4.46 & 1.01 & (5) \\
\hline Q42 & 0 & 30.0 & 0.8 & 27.5 & 41.7 & 4.87 & 0.37 & (5) \\
\hline Q43 & 0 & 9.2 & 23.3 & 0 & 67.5 & 4.67 & 0.71 & (5) \\
\hline Q44 & 9.2 & 0 & 0 & 34.2 & 56.7 & 4.56 & 0.55 & (5) \\
\hline Q45 & 0 & 11.7 & 0 & 38.3 & 50.0 & 4.43 & 1.08 & (5) \\
\hline Q46 & 0 & 13.3 & 28.3 & 7.5 & 50.8 & 3.87 & 1.05 & (4) \\
\hline Q47 & 0 & 0 & 7.5 & 33.3 & 59.2 & 4.03 & 0.98 & (4) \\
\hline Q48 & 0 & 7.5 & 9.2 & 38.7 & 48.7 & 4.23 & 0.90 & (5) \\
\hline Q49 & 0 & 7.5 & 12.5 & 35.8 & 44.2 & 4.17 & 0.92 & (4) \\
\hline Q50 & 0 & 7.5 & 11.7 & 0 & 80.8 & 4.54 & 0.97 & (5) \\
\hline Q51 & 0 & 11.7 & 18.7 & 0 & 71.7 & 4.32 & 1.12 & (5) \\
\hline Q52 & 0 & 18.3 & 4.2 & 25 & 52.5 & 4.12 & 1.14 & (4) \\
\hline Q53 & 0 & 11.7 & 21.7 & 32.5 & 34.2 & 3.89 & 1.01 & (4) \\
\hline Q54 & 0 & 13.3 & 13.3 & 11.7 & 61.7 & 4.22 & 1.12 & (5) \\
\hline Q55 & 0 & 4.2 & 20.8 & 35.0 & 40.0 & 4.11 & 0.88 & (4) \\
\hline Q56 & 0 & 4.2 & 20.0 & 13.3 & 62.5 & 4.34 & 0.94 & (5) \\
\hline Q57 & 0 & 35.0 & 0 & 7.5 & 57.5 & 3.88 & 1.41 & (4) \\
\hline Q58 & 0 & 0 & 23.3 & 13.3 & 63.3 & 4.40 & 0.84 & (5) \\
\hline Q59 & 0 & 14.2 & 9.2 & 30.8 & 45.8 & 4.08 & 1.06 & (4) \\
\hline Q60 & 0 & 0 & 22.5 & 24.2 & 53.3 & 4.31 & 0.82 & (5) \\
\hline Q61 & 0 & 0 & 26.7 & 20.8 & 52.5 & 4.26 & & (5) \\
\hline Q62 & 0 & 11.7 & 14.2 & 8.3 & 85.8 & 4.28 & 1.09 & (5) \\
\hline Q63 & 0 & 5.0 & 19.2 & 23.3 & 52.5 & 4.23 & 0.93 & (5) \\
\hline Q64 & 0 & 0 & 47.5 & 19.2 & 33.3 & 3.86 & 0.89 & (4) \\
\hline
\end{tabular}




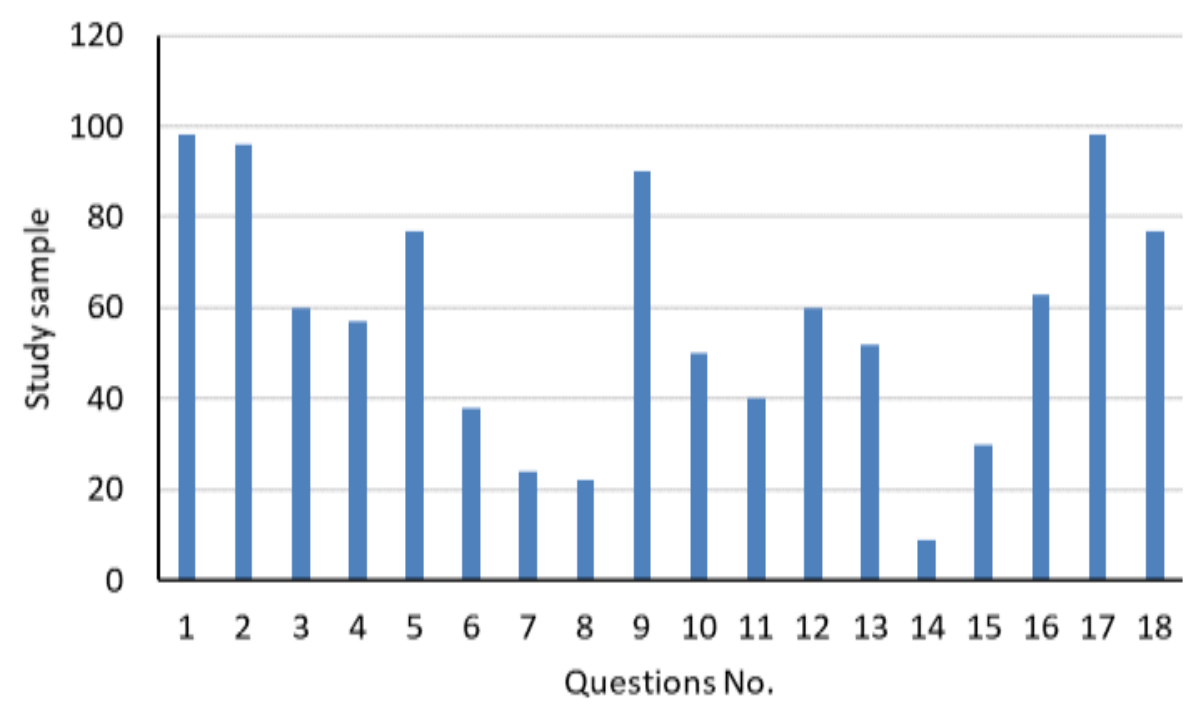

Fig. 1. Questionnaires results of accident reasons

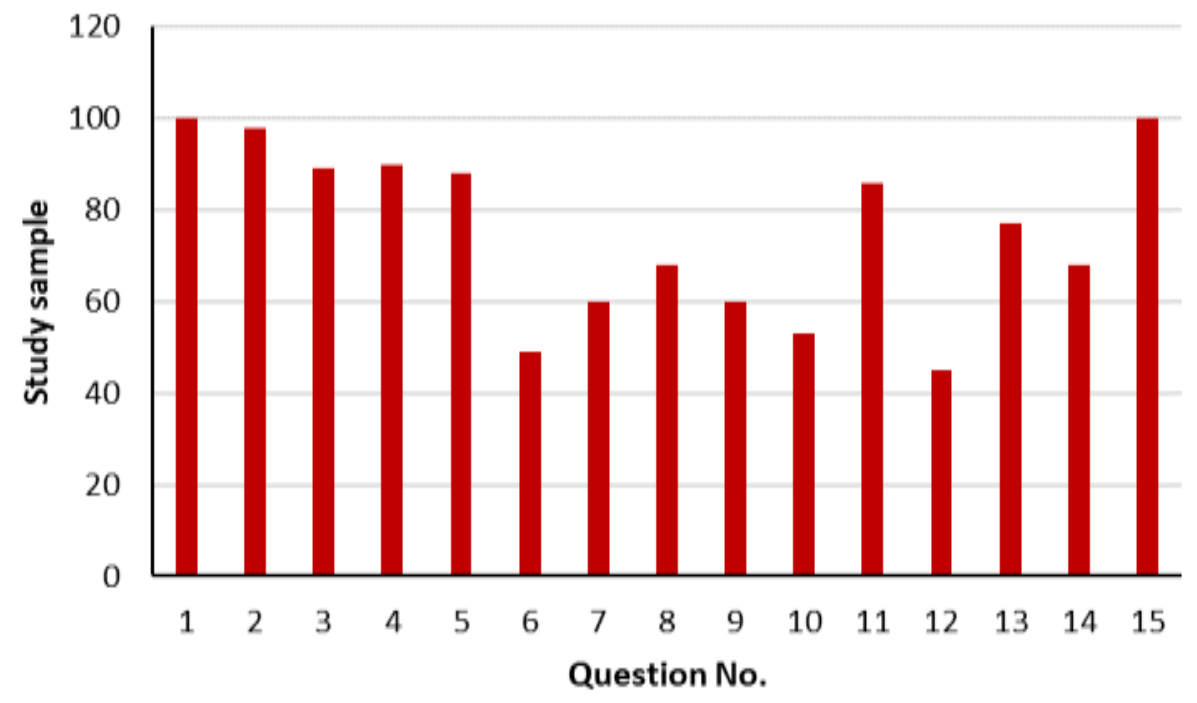

Fig. 2. Questionnaires results of quality
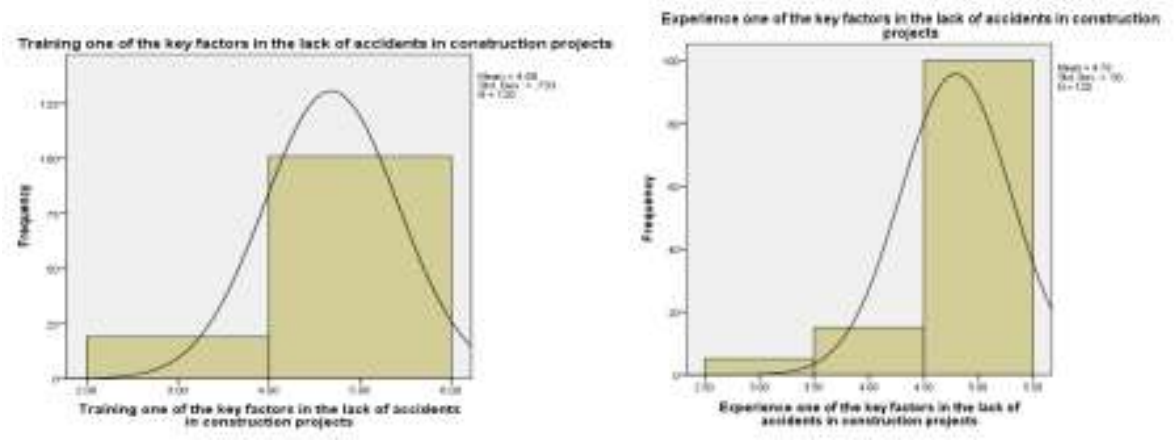

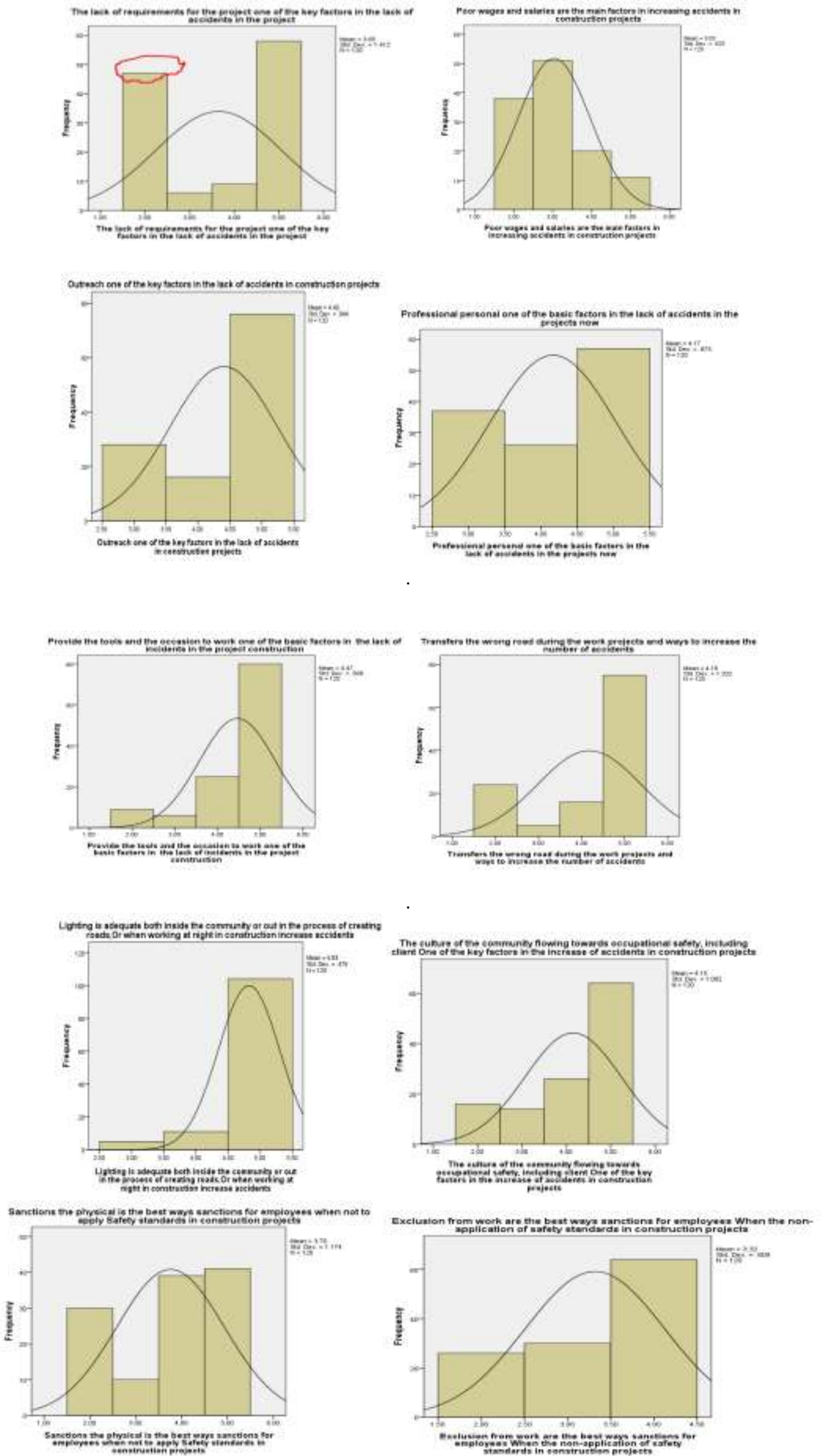

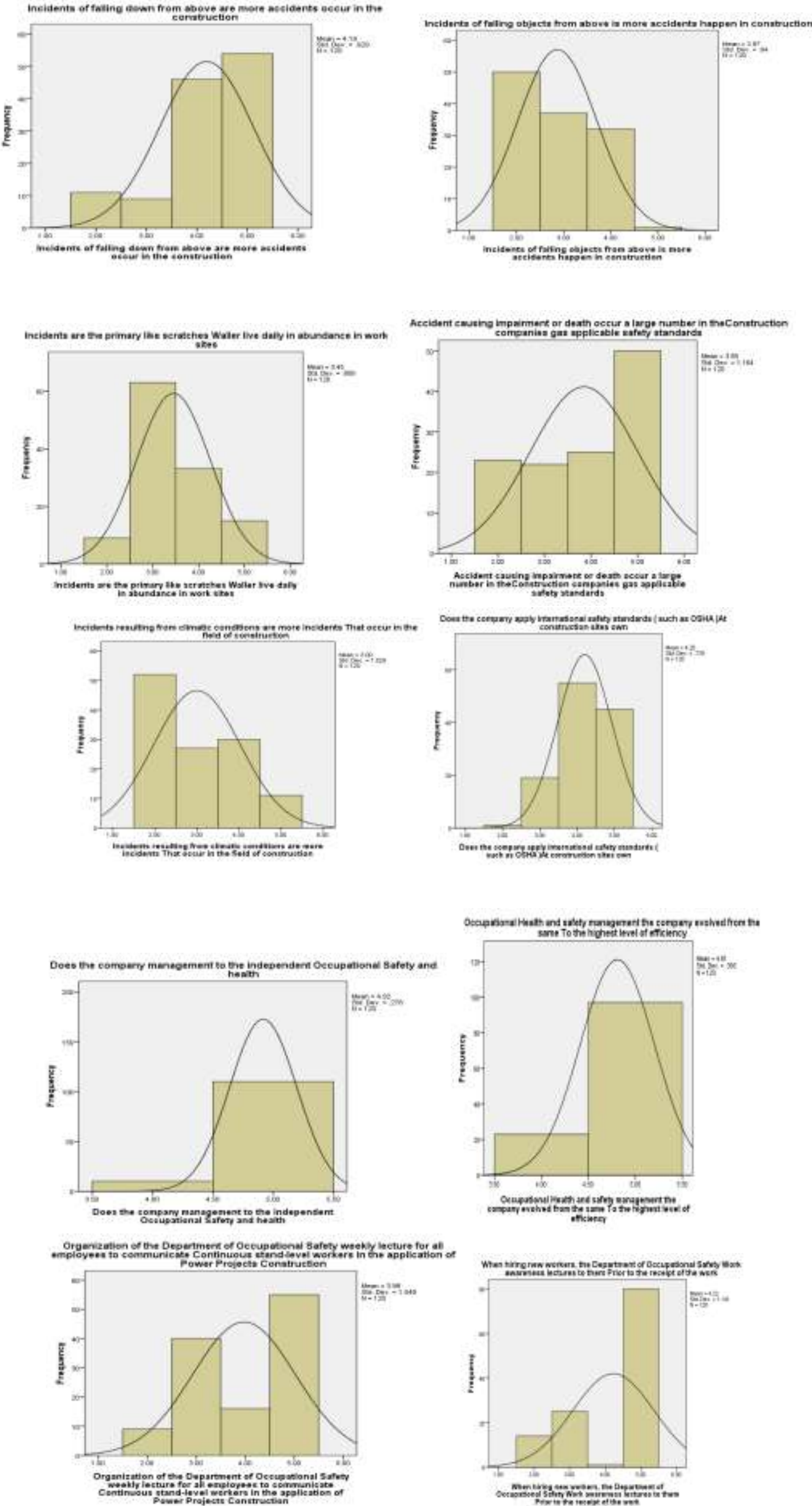


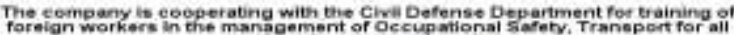
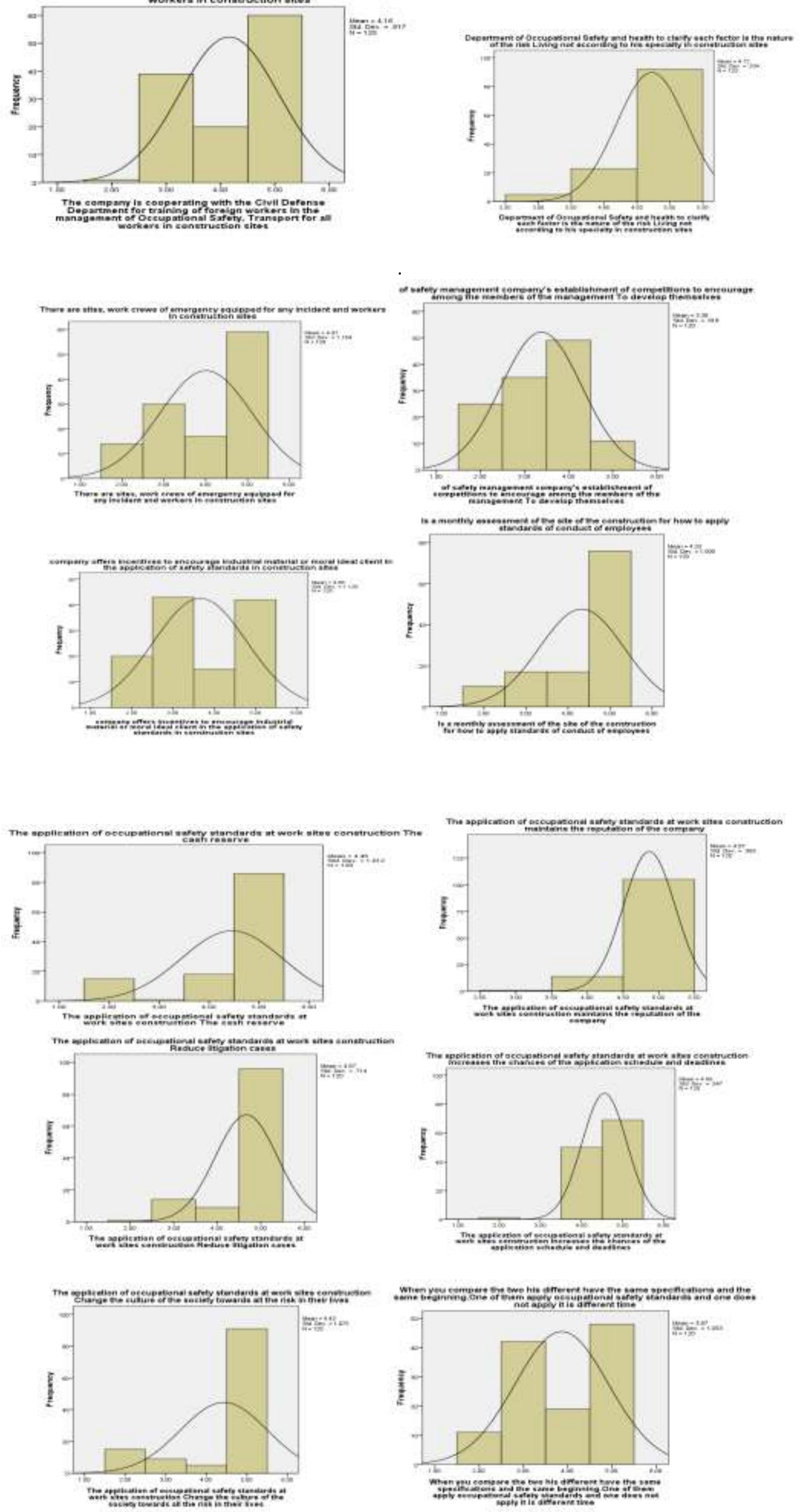


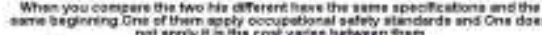

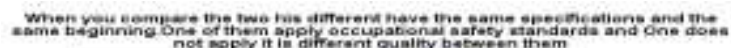
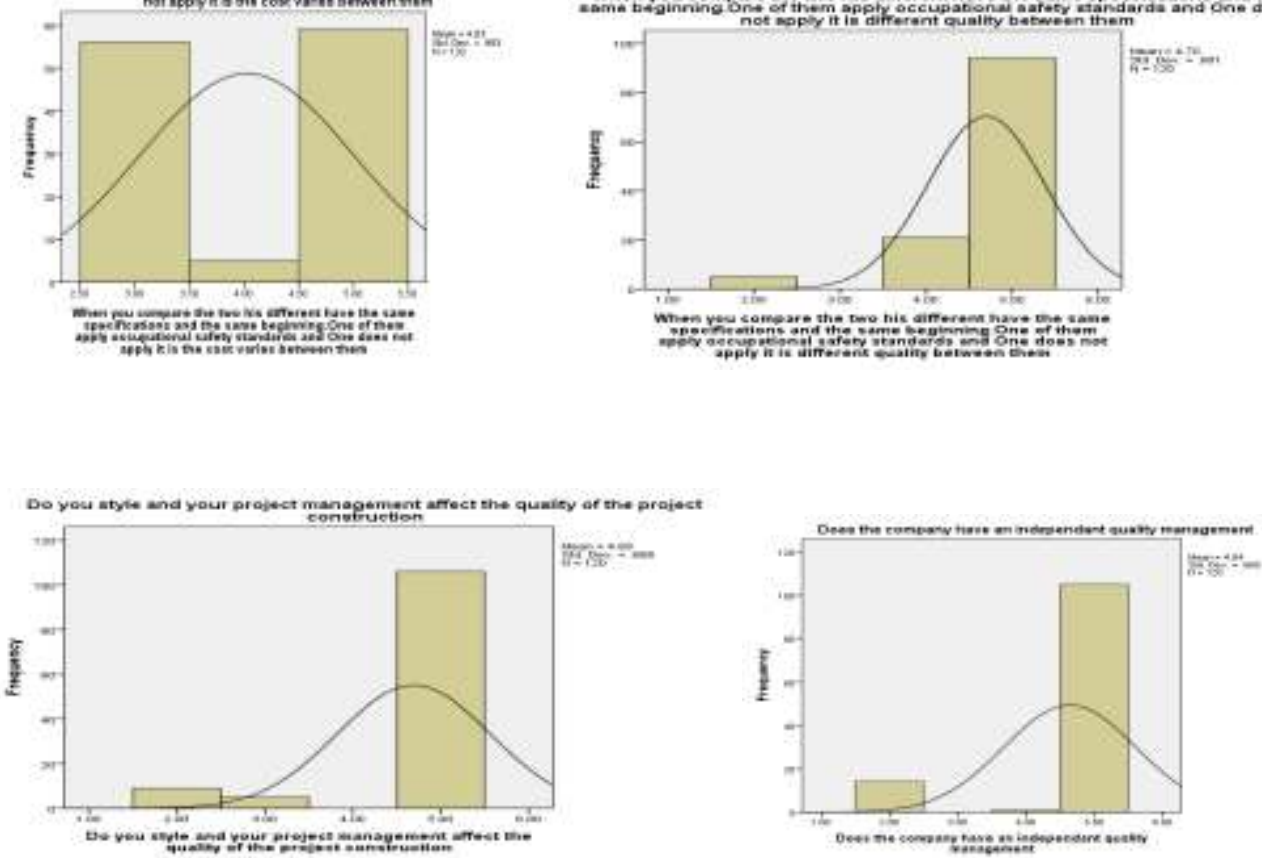

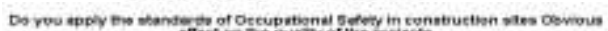
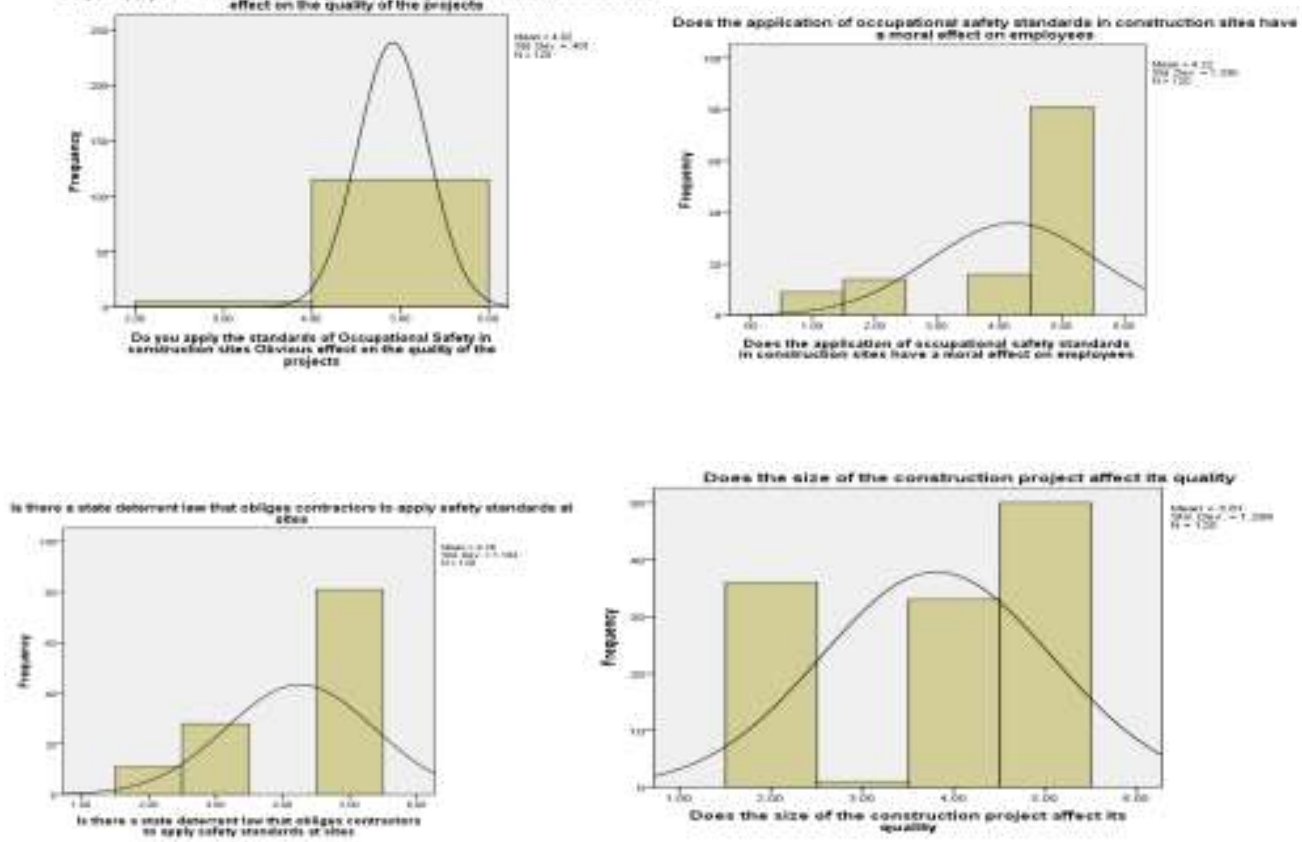

Does the comparny quality managinat have all the powers to reach the
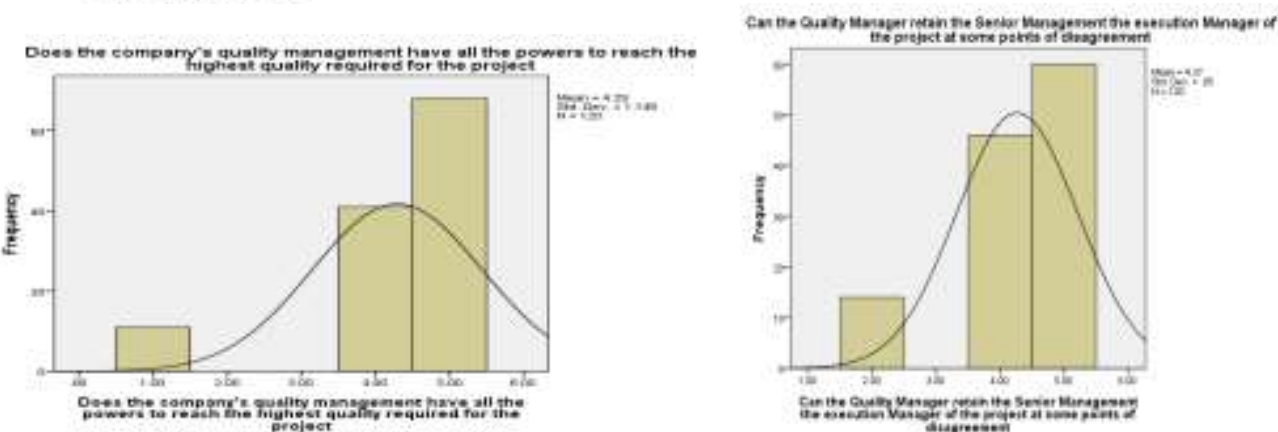

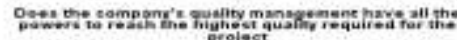
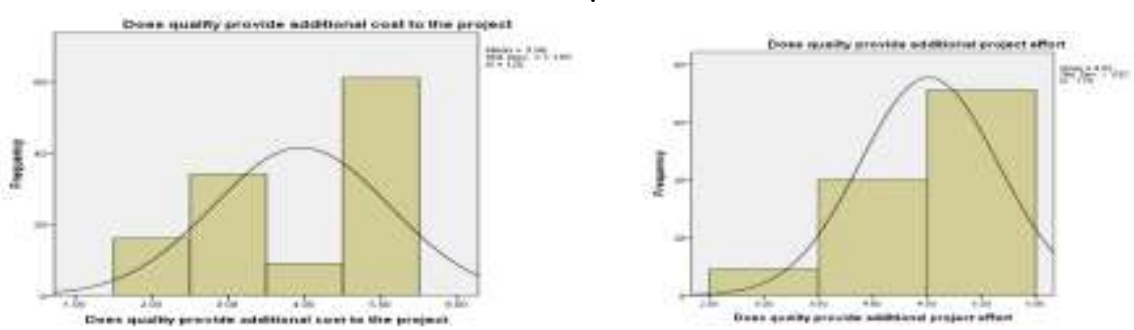
Journal of University of Shanghai for Science and Technology
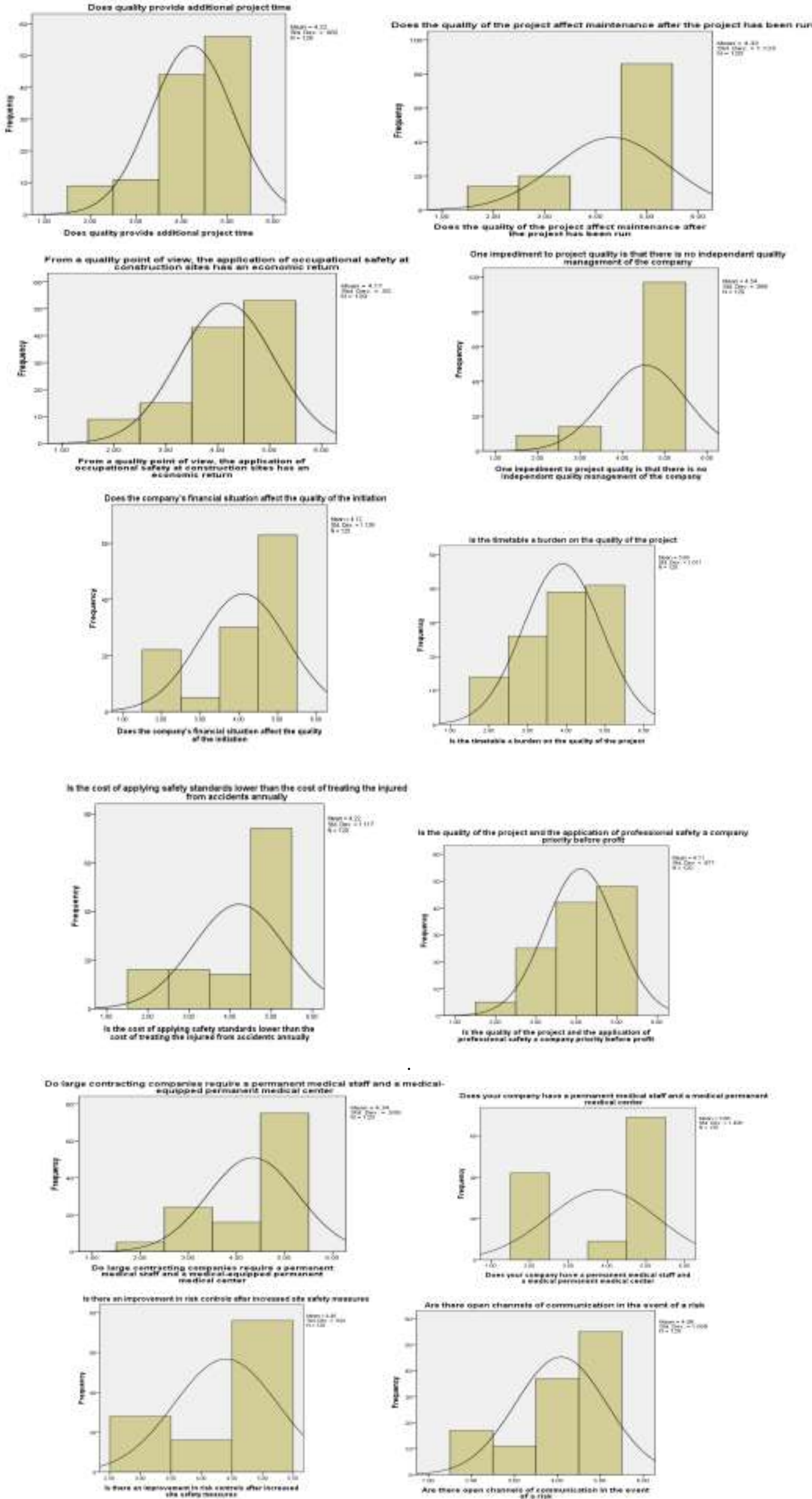

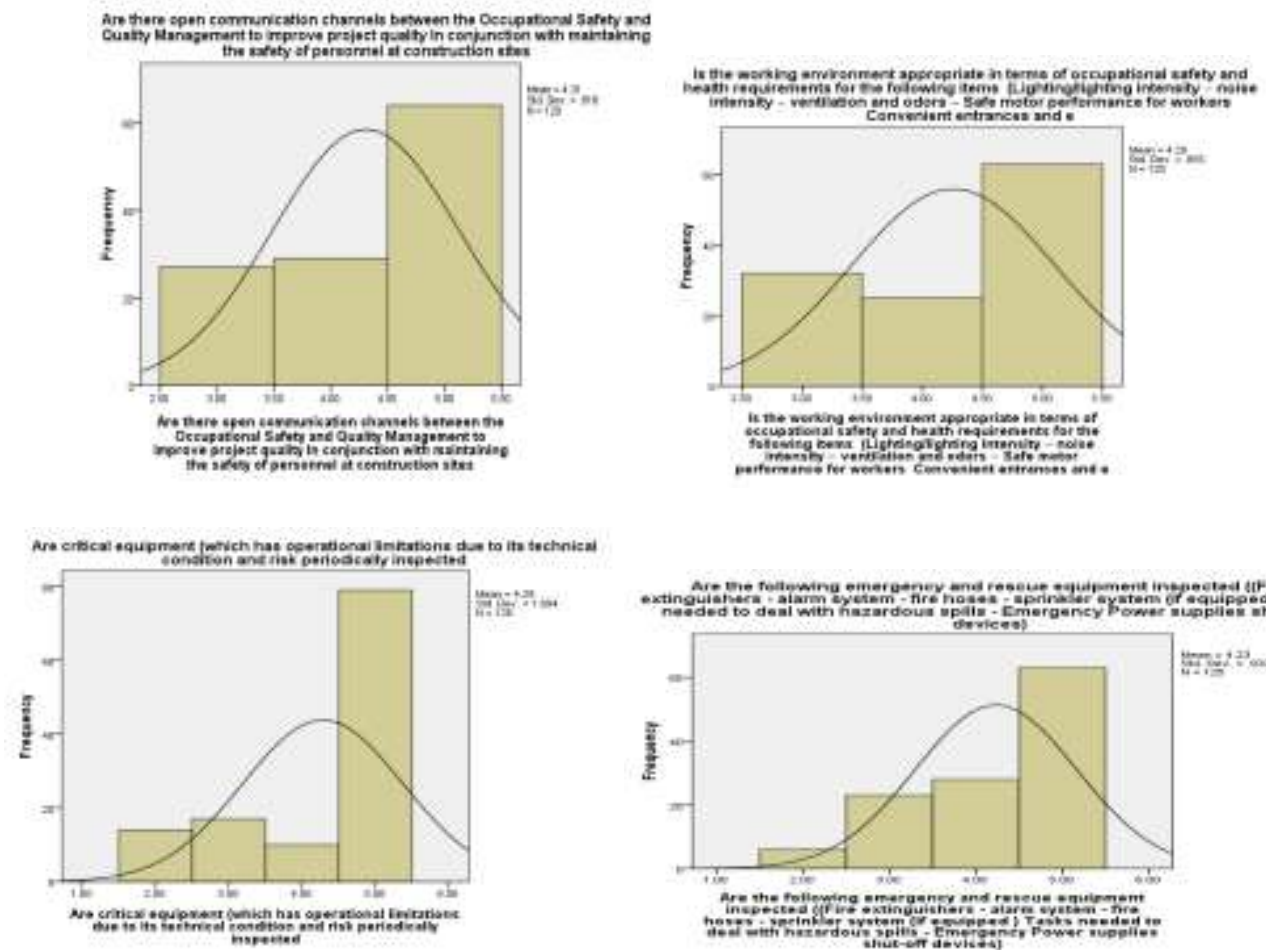

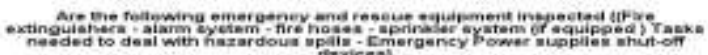
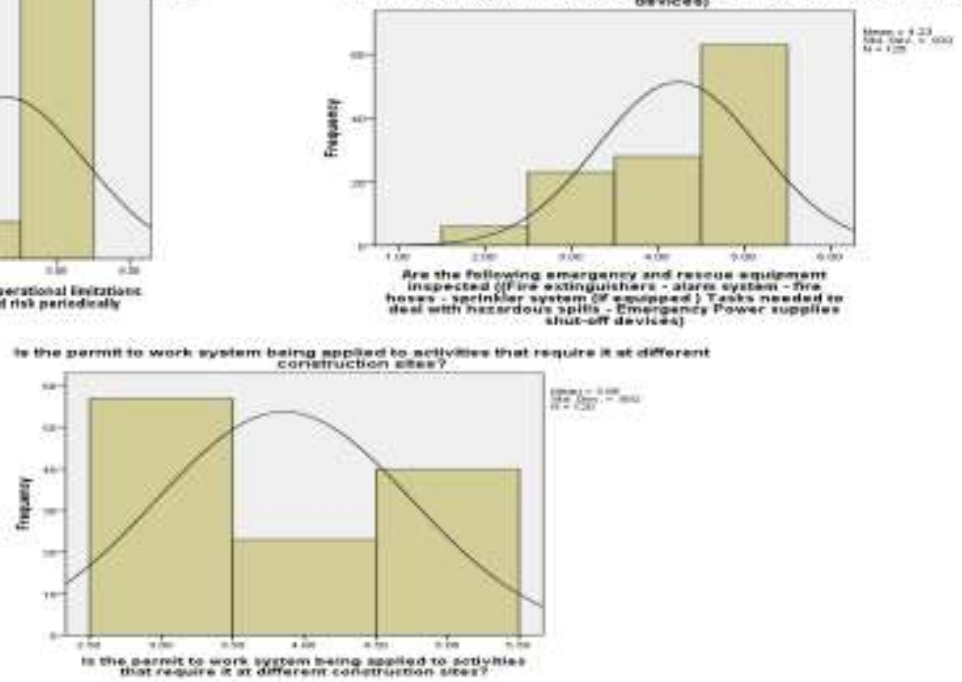

Fig. 3. Statistical analysis results for each question 


\section{e) Conclusions}

The following conclusions were obtained for this work:

1- A deterrent law that obliges contractors to apply safety standards at sites may have positive effects on the implementation of $\mathrm{OSH}$ standards among Egyptian construction companies.

2- Chances of accidents in construction sites are higher at the end of the month than at the beginning of the month due to poor wages and salaries given to workers, which drive them to do poor-quality work. Therefore, companies must review the wages and salariesto improve theworkers'satisfactionand, therefore, the quality of theirwork.

3- It is necessary to maintain an Internet connection for the OSH department so that it can communicate with global specialists and keep up to date with the latest methods and safety systems, thus benefiting from the experiences of others. The OSH department must cooperate with the Ministry of Manpower and review relevant proposals to improve work conditions in construction sites.

4- Companies should hire a social worker to take care of the workers, help them solve their problems, and ensure that safety standards are being met in the construction sites. In addition, regular medical examinations of all workers must be conducted to ensure that they are free from any occupational, non-infectious, or infectious diseases, such as the coronavirus.

5- There should be clear set of criteria on the appropriate work procedures as well as the acceptance or rejection of work outcomes. The stages of project construction must be documented from the conceptualization stage up to the maintenance operation. There should also be a trusted program for each company's internal audit.

6- There should be a technical college devoted to applied sciences and OSH as well as secure work environments and TQM to qualify the skilled inspectors in the market. It is also necessary to develop a special OSH department in the universities and increase the amount of teaching materials and credit hours for college students to further promote awareness of OSH and TQM.

7- The application of occupational safety standards in construction sites saves money, promotes the company's reputation, reduces litigation cases, increases the chances of completing schedules and deadlines, and changes the organizational culture regarding safety and various kinds of risks. 


\section{f) Recommendations}

The following are the recommendations arising from this work:

1. Establish an application program to assess the impact of OSH on the quality of construction and architectural projects using artificial intelligence.

2. Establish a program to assess the impact of corporate management behavior on quality.

3. A study to compare the cost results when using OSH standards and the costs of occupational accidents in engineering projects.

\section{References}

1. Waehrer GM, Dong XS, Miller T, Haile E, Men Y. Costs of occupational injuries in construction in the United States. Accident Analysis \& Prevention 2007 1;39(6):1258 -66. https://doi.org/10.1016/j.aap.2007.03.012

2. Huang X, Hinze J. Analysis of construction worker fall accidents. Journal of construction engineering and management 2003;129(3):262-71. https: / / doi.org/10.1061/(ASCE)0733-9364(2003)129:3(262)

3. Lingard $H$, Rowlinson S. Occupational health and safety in construction project management. London, United Kingdom: Routledge; 2004. https://doi.org/ 10.4324/9780203507919

4. European Commission. Non-binding guide to good practice for understanding and implementing Directive 92/57/EEC. Construction Sites. Luxembourg; 2011. https://doi.org/10.2767/31797

5. Berger J. The Health and Safety Protection Plan and the File containing Features of the Building according to EEC Directive (92/57). The Management of Construction Safetyand Health, Rotterdam, Netherlands, Balkema. 2000:39-46.

6. Tan 0 . Analysis and comparison of the cost of the measures to be taken before the occupational accident occurs and the expenditure costs after the occupational accident occurs. (M.Sc.) Istanbul University, Institute of Health Sciences, Istanbul; 1999.

7. Korkutan NT. Impact of occupational health and safety costs on total costs of building construction. (M.Sc.) Istanbul Technical University, Institute of Science and Technology, Istanbul; 2010. http:// hdl.handle.net/11527/7273

8. EUROPEO CEYS. Opinion of the European Economic and Social Committee Communication from the Commission to the European Parliament, the Council, the European Economic and Social Committee and the Committee of the Regions "The role of transforming waste into energy". Official Journal of the European Union 2017; 13:102-109.

9. Campbell F. Occupational stress in the construction industry. Berkshire, UK: Charteredlnstituteof Building.2006.

10. Bowen $P$, Edwards $P$, Lingard H, Cattell K. Workplace stress, stress effects, and 
coping mechanisms in the construction industry. Journal of Construction Engineering and Management 2014;140(3):04013059.

https://doi.org/10.1061/(ASCE)C0.1943-7862.0000807

11.Spielberger CD. Job stress survey. The Corsini Encyclopedia of Psychology. 2010. https://doi.org/10.1002/9780470479216.corpsy0478

12. Gürcanli GE, Müngen U. An occupational safety risk analysis method at construction sites using fuzzy sets. International Journal of Industrial Ergonomics. 2009;39(2):371-87. https://doi.org/10.1016/j.ergon.2008.10.006

13. Beriha GS, Patnaik B, Mahapatra SS, Padhee S. Assessment of safety performance in Indian industries using fuzzy approach. Expert Systems with Applications 2012;39(3):3311-23. https://doi.org/10.1016/j.eswa.2011.09.018

14. Wilson JM, Koehn EE. Safety management: problems encountered and recommended solutions. Journal of construction engineering and management 2000;126(1):77-9. https://doi.org/10.1061/(ASCE)0733-9364(2000)126:1(77)

15.Dong S, Li H, Yin Q. Building information modeling in combination with real time location systems and sensors for safety performance enhancement. Safety science 2018;102:226-37. https://doi.org/10.1016/j.ssci.2017.10.011

16. Esmaeili B, Hallowell MR. Diffusion of safety innovations in the construction industry. Journal of Construction Engineering and Management 2012;138(8):95563. https://doi.org/10.1061/(ASCE)CO.1943-7862.0000499

17.Fang $D$, Jiang $Z$, Zhang $M$, Wang $H$. An experimental method to study the effect of fatigue on construction workers' safety performance. Safety science 2015;73:8091. https://doi.org/10.1016/j.ssci.2014.11.019

18.Lu W, Huang GQ Li H. Scenarios for applying RFID technology in construction project management. Automation in construction 2011;20(2):101-6. https://doi.org/10.1016/j.autcon.2010.09.007

19. Yuan X, Anumba CJ. Cyber-Physical Systems for Temporary Structures Monitoring. In Cyber-Physical Systems in the Built Environment 2020:107-38. https://doi.org/10.1007/978-3-030-41560-0_7

20.Yang $H$, Chew $D A, W u W$, Zhou Z, Li Q. Design and implementation of an identification system in construction site safety for proactive accident prevention. Accident Analysis \& Prevention 2012;48:193-203. https://doi.org/10.1016/j.aap.2011.06.017

21.Teizer J, Allread BS, Fullerton CE, Hinze J. Autonomous pro-active real-time construction worker and equipment operator proximity safety alert system. Automation in construction 2010;19(5):630-40. https://doi.org/10.1016/j.autcon.2010.02.009

22. Machida S, Bachoo P. Guidelines on occupational safety \& health management systems. African newsletter on occupational health and safety 2001;11(3):68-9.

23.OHSAS BS. 18001: 2007 Occupational Health and Safety Management. London, UK; 2007. 
24.EASHW. "European Agency for Safety and Health at Work." (E. Communities, Ed.), European Commission Senior Labour Inspectors' Committee, Belgium; 2002.

25. Razuri C, Alarcón LF, Diethelm S. Evaluating the effectiveness of safety management practices and strategies in construction projects. In Proceedings of the $15^{\text {th }}$ Conference of the IGLC, Michigan, USA, 2007;271-281.

26. Razuri C, Alarcón LF, Diethelm S. Evaluating the effectiveness of safety management practices and strategies in construction projects. In Proceedings of the 15th Conference of the IGLC, Michigan, USA 2007;271-81.

27. Chi CF, Chang TC, Ting HI. Accident patterns and prevention measures for fatal occupational falls in the construction industry. Applied ergonomics 2005;36(4):391- 400. https://doi.org/10.1016/j.apergo.2004.09.011

28.DiDomenico AT, Lesch MF, Blair MF, Huang YH. Reaching on ladders: do motivation

\& acclimation affect risk taking?. Professional Safety 2013;58(02):50-3.

29.Gillen M, Faucett JA, Beaumont JJ, McLoughlin E. Injury severity associated with nonfatal construction falls. American Journal of Industrial Medicine 1997;32(6):647- 55. https://doi.org/10.1002/(SICI)1097- 0274(199712)32:6<647::AIDAJIM11>3.0.CO;2-1

30.OSHA, 2015b. Fall Protection Tops Preliminary List of Alleged OSHA Violations in Fiscal'15, 2015.

31.Zwetsloot GI, Kines P, Wybo JL, Ruotsala R, Drupsteen L, Bezemer RA. Zero Accident Vision based strategies in organisations: Innovative perspectives. Safety science 2017;91:260-8. https://doi.org/10.1016/j.ssci.2016.08.016

32. Mosly I. Safety performance in the construction industry of Saudi Arabia. International Journal of Construction Engineering and Management 2015;4(6):23847. https://doi.org/10.5923/j.ijcem.20150406.03

33. Amiri M, Ardeshir A, Zarandi MH. Fuzzy probabilistic expert system for occupational hazard assessment in construction. Safety science 2017;93:16-28. https://doi.org/10.1016/j.ssci.2016.11.008

34. European Commission. "Eurostat: Accidents at work statistics" (2018). Eurostat.

35. Bruni M, Central Agency for Public Mobilization and Statistics Migration Data Analysis Unit. Egypt Labour Market Report: Demographic Trends, Labour Market Evolution and Scenarios for the Period 2015-2030. International Organization for Migration; 2017. http://hdl.voced.edu.au/10707/528105 